\title{
Rectal Perforation by a Balloon Spacer: A Rare Cause of Rectal Perforation Addressed Endoscopically
}

\author{
Sónia Barros ${ }^{\mathrm{a}}$ Joana Roseira ${ }^{\mathrm{a}}$ Paulo Caldeira ${ }^{\mathrm{a}}$ Ana Margarida Vaz ${ }^{\mathrm{a}}$ \\ Horácio Guerreiro $^{\mathrm{a}}$ Oscar Codon $^{\mathrm{b}}$ \\ ${ }^{a}$ Gastroenterology Department, Algarve University Medical Center, Faro, Portugal; ${ }^{b}$ Radiation Oncology \\ Department, Algarve Radio-Oncology Clinic, Faro, Portugal
}

\section{Keywords}

Intensity-modulated radiotherapy · Adverse effects · Rectal spacer $\cdot$ Rectal perforation $\cdot$ Endoscopy

\section{Abstract}

Prostate cancer is the second most frequent cancer in men worldwide. Dose escalation is currently the standard of care for the treatment of prostate cancer with radiation therapy. However, the rectum tends to be the dose-limiting structure when treating prostate cancer, given its proximity. The injection of biodegradable spacers between the prostate and the rectum may optimize radiotherapy treatment delivery for patients with localized disease. Nevertheless, although the overall complication rate of spacers is marginal, the benefits of spacer technologies need to be evaluated against the complication risks such as rectum perforation/necrosis. We report a case of a 59-year-old man with a diagnosis of prostate adenocarcinoma for whom hormonal treatment followed by intensity modulated radiation therapy (IMRT) was proposed. A biodegradable and expandable balloon (BioProtect ${ }^{\circledR}$ ) was injected into the perirectal space without detectable immediate complications. One month later, the patient presented with a 3-day persistent rectal bleeding. The investigation confirmed a rectal perforation by the balloon spacer system.

(C) 2020 Sociedade Portuguesa de Gastrenterologia Published by S. Karger AG, Basel
Perfuração rectal por balloon spacer: uma causa rara de perfuração com resolução endoscópica

\section{Palavras Chave}

Radioterapia com intensidade modulada - Efeitos adversos · Rectal spacer · Perfuração retal · Endoscopia

\section{Resumo}

O cancro da próstata é atualmente, em todo o mundo, o segundo cancro mais frequente no homem. As recomendações atuais indicam o uso doses de radiação progressivamente maiores ao longo do processo de radioterapia no tratamento do cancro da próstata. Contudo, a proximidade anatómica do reto é um fator limitante na dose de radiação usada ao longo do tratamento. A colocação de espaçadores biodegradáveis entre a próstata e o reto pode otimizar o tratamento de radioterapia em doentes com doença localizada. No entanto, embora a taxa de complicações dos espaçadores seja reduzida, o benefício desta técnica precisa de ser contrabalançada com o risco de complicações, como perfuração/necrose do reto. Apresentamos o caso de um paciente do sexo masculino de 59 anos com diagnóstico de adenocarcinoma da próstata para o qual foi proposto tratamento hormonal seguido de radioterapia com intensidade modu- karger@karger.com www.karger.com/pjg

Karger $\stackrel{\text { ' }}{5}$ BOPEN ACCESS
(C) 2020 Sociedade Portuguesa de Gastrenterologia. Published by S. Karger AG, Basel

This article is licensed under the Creative Commons AttributionNonCommercial-NoDerivatives 4.0 International License (CC BYNC-ND) (http://www.karger.com/Services/OpenAccessLicense). Usage and distribution for commercial purposes as well as any distribution of modified material requires written permission.
Sónia Barros

Gastroenterology Department

Algarve University Medical Center

R. Leão Penedo, PT-8000-386 Faro (Portugal)

soniaisb@ hotmail.com 
lada (IMRT). Um balão biodegradável e expansível (BioProtect ${ }^{\circledR}$ ) foi injetado no espaço peri-retal sem complicações imediatas detetáveis. Após um mês, o paciente apresentou hematoquézias persistentes durante três dias. A investigação confirmou tratar-se de uma perfuração retal pelo balloon spacer.

(๑) 2020 Sociedade Portuguesa de Gastrenterologia Publicado por S. Karger AG, Basel

\section{Introduction}

Radiotherapy (RT) takes part in the management of prostate adenocarcinoma [1]. Advances in radiation delivery and imaging have triggered the development of targeted, high-dose radiotherapy (IMRT). However, rectal toxicity may restrain $\mathrm{RT}$ due to the rectum and prostate-close anatomy [2]. In the acute setting, radiation can cause ulceration and rectal edema. Chronic radiation proctitis can continue from the acute phase or reoccur, resulting in ischemia [1]. Argon plasma coagulation is the utmost endoscopic management of bleeding radiation proctitis. However, repetitive applications are required, it has little effect on urgency or incontinence, and it is not without complications. Additionally, hyperbaric oxygen therapy is emerging but it is not widely available, and surgery conveys a significant risk of iatrogenic injuries [1]. Apart from higher dose and larger radiation fields, other risk factors for rectal toxicity are non-modifiable: history of abdominal surgery; collagen disease; age; diabetes, hemorrhoids, and inflammatory bowel disease [2]. A spacer placed between the prostate and the rectum can be used to displace it from the high-dose zone [3]. Biodegradable spacers, including hydrogel, hyaluronic acid, collagen or an implantable balloon, can be placed in an easy manner. Overall, these spacers have an excellent safety profile and placement is well-tolerated [4]. As for balloon spacers in particular, they were created to be transperineally implanted, guided by transrectal ultrasound, within the prostate-rectum interspace, in the Denonvilliers' fascia. After positioning the insertion spacer, the balloon is filled with sterile saline. The procedure may be performed by an expert, under local anesthesia [5]. The system stays inflated during the full treatment period and posteriorly biodegrades [6]. Few and rare complications have been documented in addition to perianal discomfort during placement [7].

\section{Case Presentation}

We report the case of a 59-year-old man with a diagnosis of prostate adenocarcinoma (cT2N0M0, stage IIIC), proposed to complete hormonal treatment followed by IMRT. In order to minimize rectal irradiation, an ultrasound-guided balloon spacer (BioProtect ${ }^{\circledR}$ ) was implanted using blunt dissection. One month after the device placement, the patient presented with a 3-day persistent rectal bleeding. A digital rectal examination identified a flexible foreign body that appeared to be in continuity with the anterior rectal wall. A sigmoidoscopy showed a partly implanted foreign body in the rectal wall, above the dentate line, compatible with a rectal perforation by the spacer. Cautious removal was carried out on several fragments with biopsy forceps and a polypectomy snare (Fig. 1). After extraction, a small fistula orifice was observed, with no complication signs, and so, fistula closure was not attempted and no antibiotics were given. Two weeks later, a follow-up endoscopy was performed showing only a small papule, without fistula or ulceration (Fig. 2). Afterwards, the patient started IMRT without a spacer system. At the end of the treatment, the patient is asymptomatic.

\section{Discussion/Conclusion}

Dose-escalated radiation therapy for localized prostate cancer definitely improved disease control. However, significantly higher rectal toxicity rates resulted [2]. Rectal toxicity is regarded as the dose-limiting toxicity [2], and rectal spacers are used to reduce radiation-induced toxicity. This case describes a rare complication caused by a balloon spacer. In our case report, an expert radiologist performed the balloon spacer placement maneuvers without detectable immediate complications. We may elaborate that an unprecise positioning of the needle in the retroprostatic space behind the Denovillier fascia during the balloon placement could have been associated to this complication. Faulty needle positioning has been reported in relation to tissue adhesions and the chronic prostatitis/ inflammation process associated to adenocarcinoma [8].

Schörghofer et al. [7] has recently published the largest cohort focusing on spacers acute and subacute complications. Magnetic resonance datasets were analyzed looking for spacer deviations or post procedure hematoma. Still, balloon malrotation and hematoma formation after placement were not identified as complication predictors. Additionally, this study focused on rectal-related complications regarding balloon versus gel spacers. The overall rectal-related lesions' rate was very low, both at the implantation day and during follow-up, reinforcing the devices' safety profile. However, 5 cases of rectal perforation were recorded in patients who had a balloon spacer and there were no cases for gel systems. It matters to say that in this study the number of balloon devices significantly 
Fig. 1. Colonoscopy images showing balloon spacer inserted in the rectal wall (a). Endoscopic removal procedure in small pieces (b). Small fistula orifice (c).
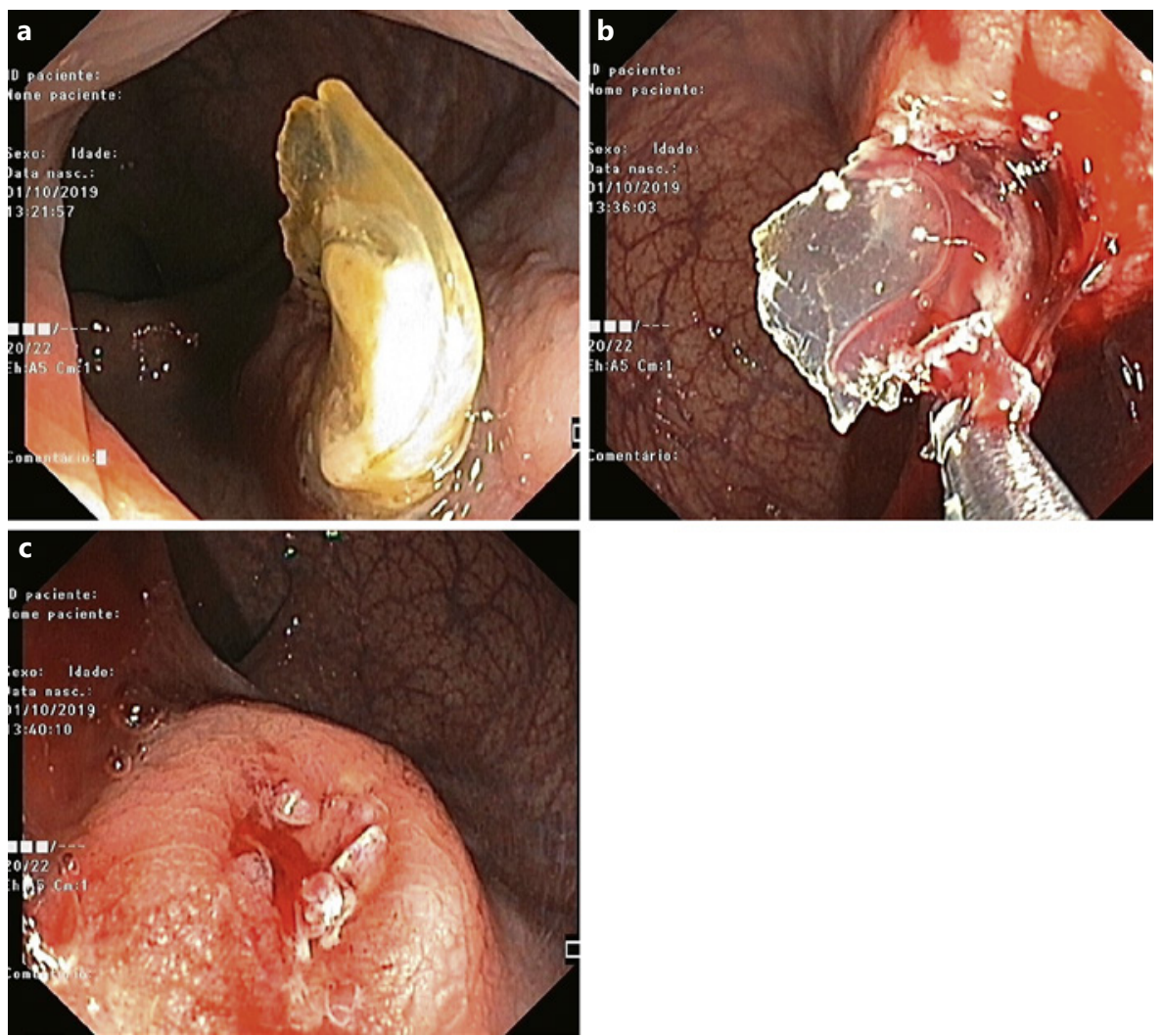

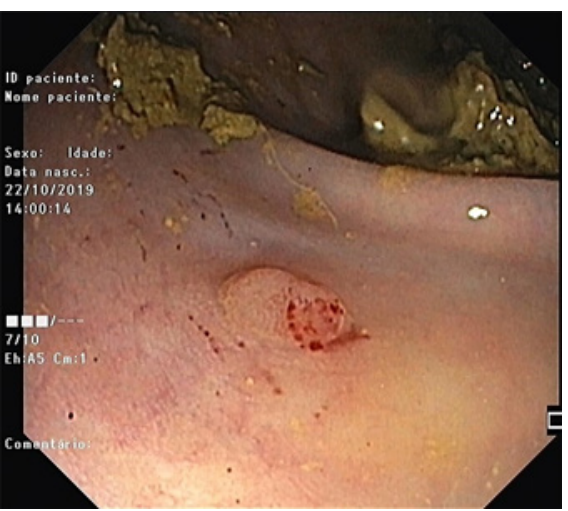

Fig. 2. Follow-up colonoscopy 2 weeks later, small papule without ulceration.

outweighed the gel devices. Also, as with our report, the perforations spontaneously healed after removal of the spacer and no surgical intervention was needed. Still, in 1 case, RT had to be interrupted. One can believe that this may have clinical implications and impact the patient's psychological well-being. Schörghofer et al. [9] stated that the balloons' rigid structure and size may make them more prone to cause rectal lesions. However, perforation has been reported for gel spacers as well in other cohorts. Still on this subject, similar rates of successful implantation are described for different spacers, but balloons are considered easier to handle [10]. From another perspective, Vanneste et al. [11] compared the cost-effectiveness of treating prostate cancer patients with IMRT and a spacer, versus IMRT only. The spacer was found to be cost-effective due to less severe toxicity, and a reduction in costs associated with side effects.

This spacer system was issued in 2010, and it is considered globally efficacious and safe. Some reports elaborate that this balloon spacer may even be more efficacious than gel spacers for rectal sparing radiation [12]. In our report, this complication was successfully addressed endoscopically, and had no impact on the patient's treatment plan. As mentioned by Schörghofer et al. [8], we believe that a decrease in major rectal toxicities with spacers in many patients, might be balanced by a slight increase in complication rates induced by the spacer, in a few patients. Nevertheless, spacer indications must not be generalized. We report the case of a patient diagnosed with stage IIIC prostate adenocarcinoma, proposed for IMRT. There is no expectable advantage for spacers during standard regimens. In higher-dose regimens, rectum 
spacer benefits become more likely to outweigh their risks [8]. Studies on virtual spacers were already performed, and this method may allow to estimate the dose-sparing benefit prior to its placement, and therefore tailor the decision of a spacer implantation [13].

Summing up, the undeniable benefits of balloon spacers in terms of dose sparing need to be weighed against the rare but still existing risks of rectal lesions and perforation. Endoscopists should be aware of this rare scenario, and this complication should be addressed with the patient before placement of such devices.

\section{Statement of Ethics}

The authors declare that they have followed the protocols of their work center on the publication of patient data, and the patient has given written informed consent to publish her case.

\section{Conflict of Interest Statement}

The authors have no conflicts of interest to disclose.

\section{Funding Sources}

The authors received no financial support for the research, authorship or publication of this article

\section{Author Contributions}

S.B. is the article guarantor; S.B.: manuscript draft; J.R., P.C. and A.V.: manuscript edition; P.C. and J.R.: endoscopists involved in the case; O.C.: radiotherapist involved in the patient management; H.G.: critical revision of the manuscript for intellectual content. All authors revised and approved the final manuscript for submission.

\section{References}

1 Ali F, Hu KY. Evaluation and Management of Chronic Radiation Proctitis. Dis Colon Rectum. 2020 Mar;63(3):285-7.

2 Pinkawa M. Current role of spacers for prostate cancer radiotherapy. World J Clin Oncol. 2015 Dec;6(6):189-93.

3 Pinkawa M, Schubert C, Escobar-Corral N, Berneking V, Eble MJ. Optimization of prostate cancer radiotherapy using of a spacer gel, volumetric modulated arc therapy and a single biological organ at risk objective. International Journal of Radiation Research. 2018; 16(2):169-76.

4 Mok G, Benz E, Vallee JP, Miralbell R, Zilli T. Optimization of radiation therapy techniques for prostate cancer with prostate-rectum spacers: a systematic review. Int J Radiat Oncol Biol Phys. 2014 Oct;90(2):278-88.

5 Gez E, Cytron S, Ben Yosef R, London D, Corn BW, Alani S, et al. Application of an interstitial and biodegradable balloon system for prostate-rectum separation during prostate cancer radiotherapy: a prospective multicenter study. Radiat Oncol. 2013 Apr;8(1):96.

6 Pasquier D, Bogart E, Bonodeau F, Lacornerie T, Lartigau E, Latorzeff I. BioPro-
RCMI-1505 trial: multicenter study evaluating the use of a biodegradable balloon for the treatment of intermediate risk prostate cancer by intensity modulated radiotherapy; study protocol. BMC Cancer. 2018 May; 18(1):566.

7 Müller AC, Mischinger J, Klotz T, Gagel B, Habl G, Hatiboglu G, et al. Interdisciplinary consensus statement on indication and application of a hydrogel spacer for prostate radiotherapy based on experience in more than 250 patients. Radiol Oncol. 2016 Jul;50(3):329_ 36.

8 Schörghofer A, Drerup M, Kunit T, Lusuardi L, Holzinger J, Karner J, et al. Rectum-spacer related acute toxicity - endoscopy results of 403 prostate cancer patients after implantation of gel or balloon spacers. Radiat Oncol. 2019 Mar; 14(1):47.

9 Klotz T, Mathers M, Lazar Y, Gagel B. Hydrogelapplikation als Spacer in den,DenovierRaum": Optimierung der IMRT-Radiotherapie des lokalisierten Prostatakarzinoms. Urologe A. 2013;52(12):52.

10 Melchert C, Gez E, Bohlen G, Scarzello G, Koziol I, Anscher M, et al. Interstitial biode- gradable balloon for reduced rectal dose during prostate radiotherapy: results of a virtual planning investigation based on the pre- and post-implant imaging data of an international multicenter study. Radiother Oncol. 2013 Feb;106(2):210-4.

11 Vanneste BG, Pijls-Johannesma M, Van De Voorde L, van Lin EN, van de Beek K, van Loon J, et al. Spacers in radiotherapy treatment of prostate cancer: is reduction of toxicity cost-effective? Radiother Oncol. $2015 \mathrm{Feb}$; 114(2):276-81.

12 Wolf F, Gaisberger C, Ziegler I, Krenn E, Scherer P, Hruby S, et al. Comparison of two different rectal spacers in prostate cancer external beam radiotherapy in terms of rectal sparing and volume consistency. Radiother Oncol. 2015 Aug;116(2):221-5.

13 van Wijk Y, Vanneste BG, Walsh S, van der Meer S, Ramaekers B, van Elmpt W, et al. Development of a virtual spacer to support the decision for the placement of an implantable rectum spacer for prostate cancer radiotherapy: comparison of dose, toxicity and cost-effectiveness. Radiother Oncol. 2017 Oct; 125(1):107-12. 